\title{
Galba truncatula (Gastropoda, Lymnaeidae): First findings on populations showing a single annual generation in lowland zones of central France
}

\author{
Daniel Rondelaud, Philippe Hourdin, Philippe Vignoles and Gilles Dreyfuss* \\ UPRES EA n ${ }^{\circ} 3174$, Faculties of Pharmacy and Medicine, 87025 Limoges, France
}

Received 27 November 2008; Accepted 12 January 2009

\begin{abstract}
Three-year investigations were carried out in three populations of Galba truncatula to study their dynamics throughout the year when there was a single annual generation for the snail. These communities were living in permanently watered habitats, on acid soil and in lowland zones. In the three cases, egg-laying occurred from the end of June to the beginning of October and was closely associated with the summer fall in level and speed of running water. The highest numbers of egg-masses were noted at the end of July and the beginning of August. Newborns which hatched from these egg-deposits showed a strong decrease of their number from July to October and this diminution continues up to next June (at 3.4 snails per $\mathrm{m}^{2}$ of habitat). Juvenile snails measuring $\leq 2 \mathrm{~mm}$ in height were observed up to the end of next March. Compared to single annual generations of $G$. truncatula studied by other authors in zones of higher elevation, the longer period of egg-laying must be related to the local climatic and hydrologic conditions which are more favourable in lowlands than in elevation. The strong decrease in the number of snails throughout the year and the presence of a few $\leq 2$-mm high juveniles during winter months might be explained by the characteristics of running water in these permanent habitats. Indeed, the high level and the great speed of running water during most months of the year would have an effect upon the number and the growth of these snails by causing unfavourable conditions for their life.
\end{abstract}

Key words: Annual generation / Galba truncatula / snail ecology / population dynamics / wetlands

\section{Introduction}

In Western Europe, Galba truncatula O.F. Müller, 1774 is known to be the main intermediate host of the parasite Fasciola hepatica Linnaeus, 1758. The number of snail generations throughout the year determines the number of periods for which cercarial shedding occur and, subsequently, that of risk periods for local livestock and wild big mammals. Under normal climatic conditions, two generations of $G$. truncatula, the first in spring and the other in autumn, were found. During very wet years, three generations (spring, summer and autumn) were noted (Taylor, 1965). However, a single annual generation of $G$. truncatula was noted in most populations living along river banks (Dreyfuss et al., 1997) or in highlands (Rondelaud and Mage, 1992; de Massias et al., 1996).

\footnotetext{
*Corresponding author: gilles.dreyfuss@unilim.fr
}

The dynamics of populations showing a single generation per year is difficult to study. Indeed, along river banks located in plains of central France, most G. truncatula habitats were submerged from mid-November to the beginning of April so that snail counts cannot be made during this period (Dreyfuss et al., 1997). In snail populations living in highlands, the presence of snow and ice during winter months, in the French Massif Central (Rondelaud and Mage, 1992) as well as in the French Alps and Jura (de Massias et al., 1996) did not permit to follow numerical variations of snails. To bypass this difficulty, it was interesting to find $G$. truncatula populations located in lowland zones. Of the 1731 populations of $G$. truncatula recorded in the north of the Haute Vienne department (central France) below $300 \mathrm{~m}$ of elevation, only three showed a single annual generation. A three-year study was thus carried out in these sites to answer the following two questions: (i) What was the period of egg-laying in these four populations? (ii) How did the dynamics of these snails go off throughout the year? 


\section{Materials and methods}

The three populations of $G$. truncatula were living on acid soil in the department of Haute Vienne, central France. The first two inhabited road ditches permanently watered by spring heads and respectively located in the commune of Saint Jouvent $\left(45^{\circ} 57^{\prime} 25^{\prime \prime} \mathrm{N}, 1^{\circ} 10^{\prime} 20^{\prime \prime} \mathrm{E}\right)$ and in that of Veyrac $\left(45^{\circ} 52^{\prime} 45^{\prime \prime} \mathrm{N}, 1^{\circ} 5^{\prime} 55^{\prime \prime} \mathrm{E}\right)$. The habitat of the last population was located in the commune of Saint Sornin la Marche $\left(46^{\circ} 11^{\prime} 8^{\prime \prime} \mathrm{N}, 0^{\circ} 59^{\prime} 25^{\prime \prime} \mathrm{E}\right)$ and was constituted by an open drainage ditch in which water coming from a permanent spring ran throughout the year. In every case, the habitat of snails was located downstream from a drainpipe and was in the shade of high trees during the most part of the day. Except for the downstream end of the pipe which was bare, the banks of every habitat and a part of the bottom were covered by aquatic and/or semi-aquatic vegetation. Compared to other snail habitats which were less than $5 \mathrm{~m}^{2}$ on acid soil (Vareille-Morel et al., 1999), the areas occupied by snails were 13.7, 10.8 and $8.6 \mathrm{~m}^{2}$, respectively, while the corresponding numbers of overwintering G. truncatula counted in January 2004 were 107,81 and 63 .

Fortnightly investigations were carried out in these three habitats from January 2004 to December 2006. Each investigation was made on six $1-\mathrm{m}^{2}$ squares (two per snail habitat), each covering the bottom of the road ditch (or that of the drainage furrow) and the corresponding slopes on a $15-\mathrm{cm}$ height. Indeed, G. truncatula is known to be an amphibious snail (Taylor, 1965; Rondelaud, 1974). The height of the water layer, the speed of running water over a distance of $50 \mathrm{~m}$, and the temperature of water at a depth of $5 \mathrm{~cm}$ (at 2 p.m.) were first measured in the central part of every ditch. Secondly, snail counts were performed to determine the total number of snails and that of eggdeposits in every square. Thirdly, a variable number of randomly chosen snails (30-50 depending on the area of the habitat) was also collected to measure their shell height under a stereomicroscope (snails were replaced in their habitat after measures) and to determine the percentage of young snails ( $\leq 2 \mathrm{~mm}$ in height) for every date of investigation. The results obtained for every parameter during the three years were pooled and were expressed for a single year. Mean values and S.D. were calculated, taking into account the date of investigation. A Kruskal-Wallis test (Stat-Itcf, 1988) was used to establish levels of significance in the case of biological parameters.

\section{Results}

In these ditches, the mean height of the water layer (Fig. 1a) peaked at the beginning of February (at $21.1 \mathrm{~cm}$ ) and progressively decreased until the end of March before a slight augmentation at the beginning of May. Afterwards, another diminution of water height occurred up to the end of August (at $4.1 \mathrm{~cm}$ ), followed by a progressive increase up to December. A similar variation was also noted for the speed of running water (Fig. 1b) in the
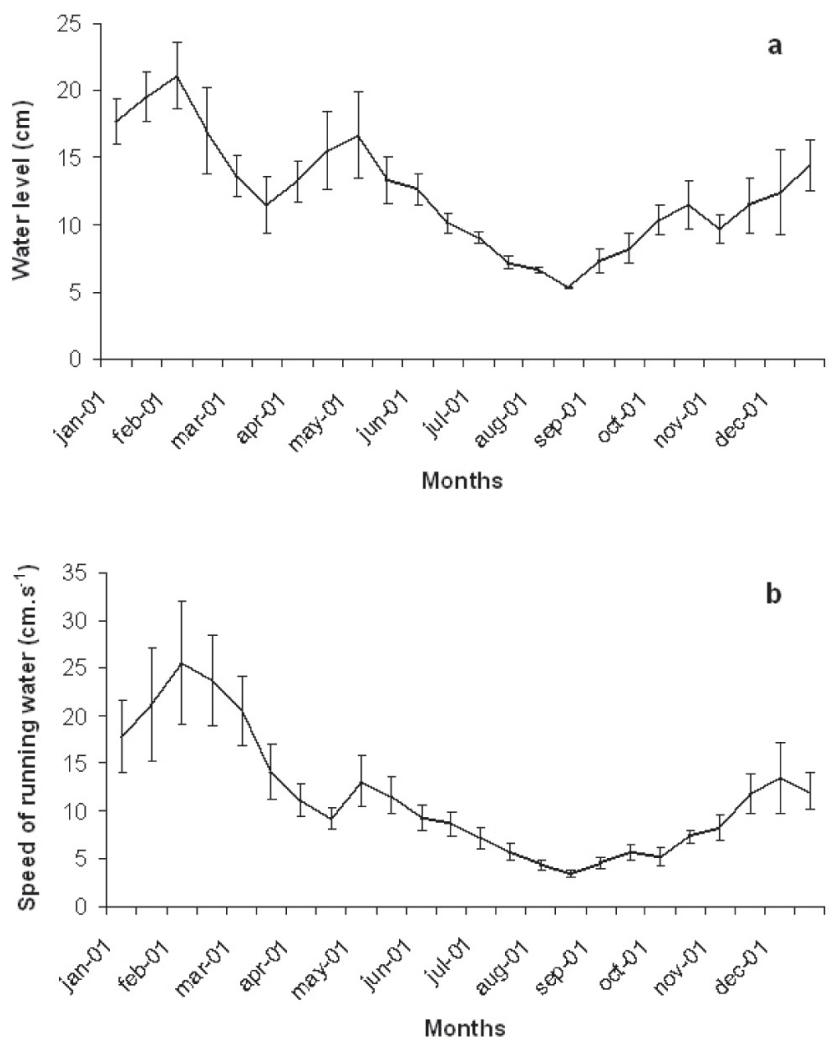

Fig. 1. Fortnightly variations of running water measured in the three habitats of G. truncatula between 2004 and 2006: the height of the water layer at the lowest point of the ditch (a) and the speed of current over a 100-m distance (b). The values recorded during the three years were pooled before being averaged and S.D. being established.

central part of ditches. After a first peak at the beginning of February and another in May, the speed progressively decreased until the end of August (at $3.5 \mathrm{~cm} . \mathrm{s}^{-1}$ ) before increasing up to December. Water temperature (data not shown) rose up to August but most values during this last month ranged only between $13{ }^{\circ} \mathrm{C}$ and $16{ }^{\circ} \mathrm{C}$ at 2 p.m.

Figure 2 shows the density of snails and that of eggmasses throughout the year. From January up to the beginning of June, the total number of overwintering G. truncatula per $1-\mathrm{m}^{2}$ square (Fig. 2a) progressively diminished up to a mean of 3.9 adults. A significant numerical increase $(\mathrm{H}=77.63, P<0.001)$ occurred from the end of June with a peak at the end of July (at 71.3 snails.m $^{-2}$ ), followed by a slight decrease of this number up to the end of September and a more important diminution until the end of the year. Compared to seasonal variation noted in the number of snails, egg-masses (Fig. 2b) were only observed from the end of June to the beginning of October. The highest figures were noted at the end of July (at $20.4 \mathrm{~m}^{-2}$ ) and the beginning of August (at $16.2 \mathrm{~m}^{-2}$ ) while other values were significantly lower $(\mathrm{H}=36.71$, $P<0.001)$. These findings indicate the occurrence of a single annual generation for $G$. truncatula in these sites, with a period of egg-deposits over 3.5-4 months. 

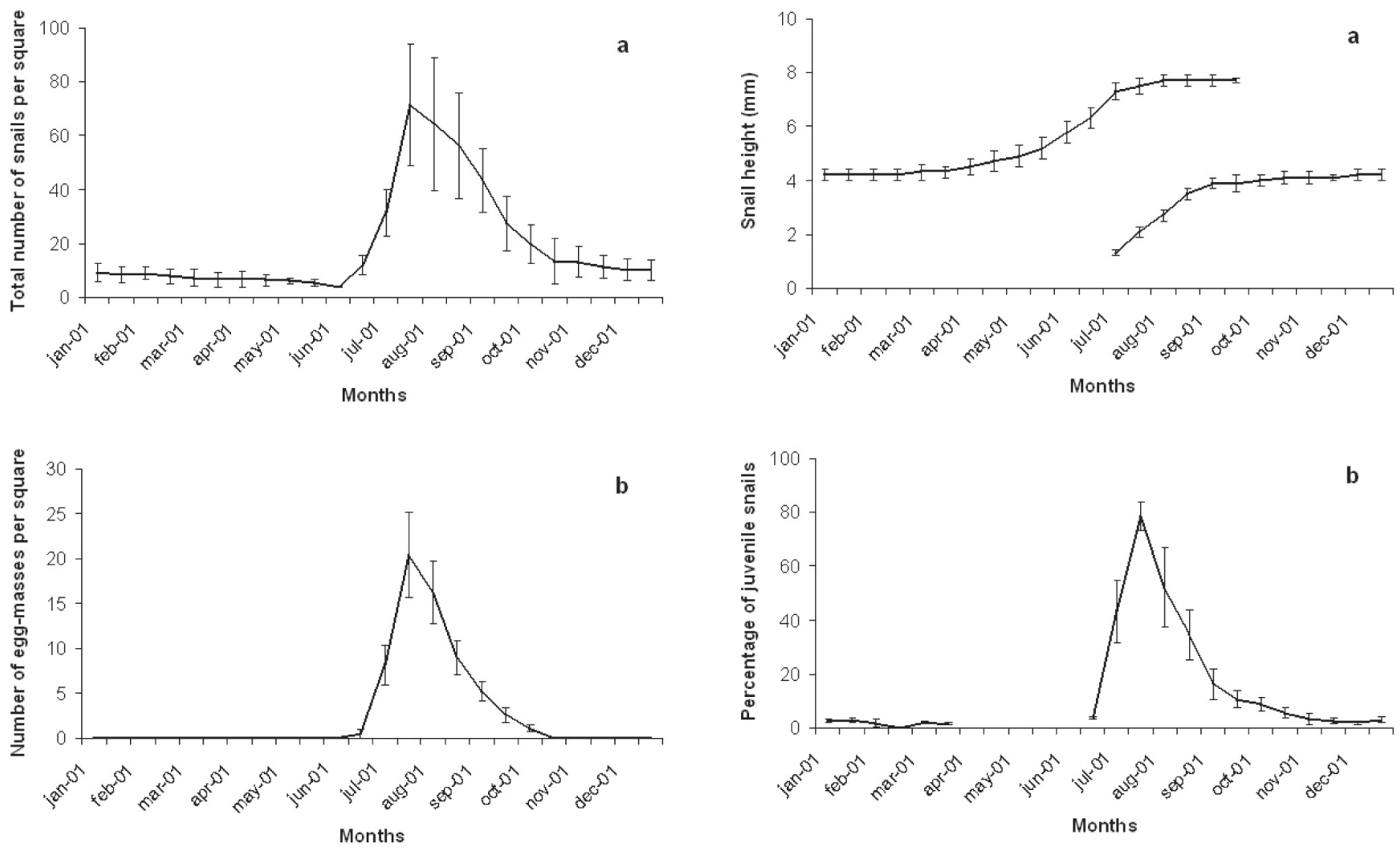

Fig. 2. Dynamics of populations in the three habitats of G. truncatula between 2004 and 2006: total number of snails per $1 \mathrm{~m}^{2}$ square (a) and total number of egg-masses per square (b). The values recorded during the three years were pooled before being averaged and S.D. being calculated.

The height of these G. truncatula and the percentage of juvenile snails are given in Figure 3. From July to October, the shell height increased up to $4.1 \mathrm{~mm}$ and was afterwards slowed down until the end of next May. A new increase occurred from June to the end of July, followed by another plateau at $7.7 \mathrm{~mm}$ in August and September. A significant variation $(\mathrm{H}=87.97, P<0.001)$ was noted for this parameter throughout the year. Among these different size classes, the young snails measuring $\leq 2 \mathrm{~mm}$ in height also showed a significant variation $(\mathrm{H}=53.95, P<0.001)$ with greater than $30 \%$ rates in July and August, whereas the other percentages progressively decreased up to the end of next March.

\section{Discussion}

In these three habitats, egg-laying of G. truncatula occurred from mid-June up to the beginning of October and was clearly longer than the 2-month period (AugustSeptember) reported by Rondelaud and Mage (1992) or by de Massias et al. (1996) for snail habitats located in zones of higher elevation (from 600 to $1950 \mathrm{~m}$ ). To explain this difference, the first interpretation is to relate this period of 3.5-4 months to local climatic and hydrologic conditions which are more favourable in lowlands than in elevation.

Fig. 3. Growth of G. truncatula in the three habitats studied from 2004 to 2006: shell height of snails (a) and percentage of juveniles measuring $\leq 2 \mathrm{~mm}$ in height (b). The values recorded during the three years were pooled before being averaged and S.D. being calculated.

Indeed, most egg-masses (Fig. 2b) were deposited from mid-July up to mid-August (instead of August in highland habitats) and their density may attain a mean of $20.4 \mathrm{~m}^{-2}$ at the end of July (instead of $8.4 \mathrm{~m}^{-2}$ in August at an elevation of $600 \mathrm{~m}$, Rondelaud and Mage, 1992).

From August, the number of snails showed a progressive decrease up to the end of next June. Indeed, it fell from $71.3 \mathrm{~m}^{-2}$ at the end of July to $10.2 \mathrm{~m}^{-2}$ at the end of December and this diminution continues the next year up to 3.9 snails. $\mathrm{m}^{-2}$ at the end of June (Fig. 2a). Apart from aestivation which causes the death of numerous snails (Taylor, 1965), the strong numerical diminution found in these permanent ditches was never observed in the case of temporary habitats located in lowlands when they are watered. According to Rondelaud (1977), the number of snails living in these temporary sites at the beginning of December was close to that found next April for the same generation of snails. This difference may be explained by assuming a greater predation of these snails by various species in these permanent habitats. More surprising is the presence of a few juveniles $(\leq 2 \mathrm{~mm})$ in these habitats from December to next March whereas the other snails seem to have a normal growth. As no snails measuring 2-2.5 mm in height were found in April, May or June, this finding is more difficult to interpret. In our opinion, the most valid hypothesis would be to consider these young snails 
as the descendants of eggs laid at the end of September and the beginning of October. The increase of water height and speed during winter months would have an effect on these snails by causing unfavourable conditions for their growth, probably by a lack of food so that this contingent of young snails finishes by disappearing.

In these permanent habitats, the mean height of adult snails was $7.7 \mathrm{~mm}$ in August and September. On acid soil, a mean height of $9 \mathrm{~mm}$ was already reported for adults living in open drainage furrows located in swampy meadows (Vareille-Morel and Rondelaud, 1972; VareilleMorel et al., 1999); in populations inhabiting river banks, the height of adults remained small and did not exceed 6-6.5 $\mathrm{mm}$ (Hourdin et al., 2006). As the maximum height of adults living in calcareous regions was $12 \mathrm{~mm}$ (Germain, 1930/1931), the low contents of calcium dissolved in water (often $<20 \mathrm{mg}$. $\mathrm{L}^{-1}$ according to Guy et al., 1996) was first considered the factor responsible to explain the smaller height of adults living on acid soil (Vareille-Morel and Rondelaud, 1972). However, this parameter is not the only responsible factor and it is necessary to find other one to explain the variations of height for adults on acid soil. As the quality and quantity of the diet provided as food for snails had an effect on the growth of G. truncatula (Kendall, 1953), the most valid hypothesis to explain these small heights of snails would be to consider these permanentlywatered ditches as snail habitats in which the food was of poor quality and/or else was insufficient in quantity. An argument supporting this interpretation was provided by Taylor (1965). According to this author, all individuals present in these permanently watered places ("reservoir habitats") remained invariably small in height.

\section{References}

de Massias E., Rondelaud D., Mage C. and Gevrey J., 1996. Lymnaea truncatula Müller dans les zones de haute altitude. Existence d'une seule génération annuelle. Bull. Soc. Fr. Parasitol., 14, 54-61.
Dreyfuss G., Vareille-Morel C. and Rondelaud D., 1997. Les habitats de Lymnaea truncatula Müller (Mollusque) le long de deux rivières. Ann. Limnol. - Int. J. Lim., 33, 67-72.

Germain L., 1930/1931. Mollusques terrestres et fluviatiles, Faune de France $n^{\circ} 21$ et $n^{\circ} 22$, Librairie de la Faculté des Sciences, Paris, 893 p.

Guy F., Rondelaud D., Botineau M., Dreyfuss G. and Ghestem A., 1996. Étude de relations entre les plantes les plus fréquentes et l'abondance de Lymnaea truncatula Müller, vecteur de Fasciola hepatica Linné dans les prairies marécageuses sur sol acide. Rev. Med. Vet. Toulouse, 147, 465-470.

Hourdin P., Vignoles P., Dreyfuss G. and Rondelaud D., 2006. Galba truncatula (Gastropoda, Lymnaeidae): effects of daily water-level variations on the ecology and ethology of populations living upstream of a dam. Ann. Limnol. - Int. J. Lim., 42, 173-180.

Kendall S.B., 1953. The life-history of Limnaea truncatula under laboratory conditions J. Helminthol., 27, 17-28.

Rondelaud D., 1974. Le cycle journalier d'activité de Galba truncatula Müller et sa relation avec le parasitisme. Ann. Parasitol. Hum. Comp., 49, 427-434.

Rondelaud D., 1977. L'évolution démographique de Lymnaea (Galba) truncatula Müller en Haute-Vienne. À propos de quatre années d'observations. Ann. Parasitol. Hum. Comp., 52, 511-520.

Rondelaud D. and Mage C., 1992. Lymnaea truncatula Müller: les conséquences d'une seule génération annuelle sur les caractéristiques de l'infestation par Fasciola hepatica L. Rev. Méd. Vét. Toulouse, 143, 843-846.

Stat-Itcf, 1988. Manuel d'utilisation, Institut Technique des Céréales et des Fourrages, Service des Études Statistiques, Boigneville, $210 \mathrm{p}$.

Taylor E.L., 1965. Fascioliasis and the liver-fluke, FAO Agricultural Studies, Roma, $\mathrm{n}^{\circ}$ 64, $235 \mathrm{p}$.

Vareille-Morel C. and Rondelaud D., 1972. Premières études des biotopes à Galba truncatula Müller dans le Nord-ouest du Limousin. Rev. Méd. Vét. Toulouse, 123, 1265-1273.

Vareille-Morel C., Dreyfuss G. and Rondelaud D., 1999. The characteristics of habitats colonized by three species of Lymnaea in swampy meadows on acid soil: their interest for fasciolosis control. Ann. Limnol. - Int. J. Lim., 35, 173-178. 